MICHAEL KNÜPPEL

Liaocheng University

michaelknueppel@gmx.net

\title{
ON CHINESE ĀHŌNG 阿訇'
}

Keywords: Hui Muslims, title/address, Persian loanword, Muslim clerics

\begin{abstract}
The miscellanea deals with the use of the title of / address to Imāms, Āhōng (阿言), among China's Hui Muslims. The title/address of Persian origin is used by different groups of speakers in various ways of pronounciation.
\end{abstract}

While on the one hand, the title/address Āhōng (阿言) - not Ahong as given e.g. in the EI-entry (Algar 1985: 731-732) - for Imāms in Chinese mostly used for Hui Muslim clerics is well known, on the other hand, its origin is still discussed. When Algar discussed the origins and spread of the Pers. title آخوند - $\bar{A} \underline{k} \bar{u}$ nd $\sim \bar{A} k \underline{o}$ nd 'religious scholar' he noted the possible borrowing into Chinese: "By contrast, there can be little doubt that ahong, the Chinese term for the imam of a mosque, is derived from ākūnd" (Algar 1985: 731-732) and referred to d'Ollone (1911: 439). In the revised/updated version of 2011 we can find the same statement. On the Persian origin of the title/address there is no doubt and it is suggested by the Hui Muslim clerics, too even though this is not a proof in linguistic sense. During the fieldwork among the Hui communities in Liáochéng some variation in pronounciation of the term could be observed. While Hui Muslim from the Western Chinese province Qinghǎi living in Liáochéng use the form $\bar{a}^{\prime} x \bar{u} n$ only, other Hui in the same town pronounce it as $\bar{a}^{\prime} x \bar{u} n \sim \bar{a}^{\prime} x u n \sim \bar{a}^{\prime} x \bar{u} m \sim \bar{a}^{\prime} x \bar{o} y \sim \bar{a}^{\prime} x^{w}$ zy - depending on the group of speakers. For the second syllable 言 Schuessler (2007) gives the Old Chinese reconstruction hwrêy, Late

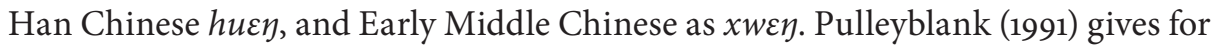

1 The paper in hand results from some fieldwork in the context of socio-linguistic research among the Hui-Muslim communities in the province of Shāndōng. The author wishes to express his thanks to Miss Sūn Mèngyáo from Liaocheng University. 
Late Middle Chinese xwa:jy and Early Mandarin xway or xuy. A. Vovin ${ }^{2}$ suggests for Late Middle Chinese more convincingly $x w \varepsilon y$ or $x w$ zy. But there are also further differences in the use of the title/address among the speakers, while the Āhongs themselves were the only ones using the title/address in its "correct" form $\bar{a}^{\prime} x \bar{o} \eta$, the members of the communities from Shāndōng pronounce it $\bar{a}^{\prime} x \bar{u} n \sim \bar{a}^{\prime} x u n \sim \bar{a}^{\prime} x \bar{u} m$ (the fluctuation was observed among female informants) $\sim \bar{a}^{\prime} x^{w} \partial \eta$. Hui Muslim from Qinghăi, for example, use the form $\bar{a}^{\prime} x \bar{u} n$ only. Another observation concerns the combination with names. While the Uyghurs ${ }^{3}$ use the title/address $\bar{a}^{\prime} x \bar{u} n$ together with the name and using the possessive (e.g. Jigdilik Mesjid'ning Imam'i Abdükerim Ahunum), the Hui-Muslim from Qīnghăi living in Shāndōng use the title/address isolated and seemingly avoid the name of the respective Imām. In case of the Hui from Liáochéng the situation is different: they also avoid the personal names and just use the title/address, but sometimes combine it with the family name of the respective Āhōng, e.g. Wǔ Āhōng (= Imām Wǔ; name of the Āhōng of the so-called "East mosque" in Liáochéng $\left.{ }^{4}\right)$.

\section{References}

Algar H. 1985. Āk̄ūnd. - Encyclopaedia Iranica. [vol. 1 (7)]. London. Bosworth C.E. 1997. Al-Ṣīn. - The Encyclopaedia of Islam. [New edition, vol. 9]. Leiden. d'Ollone H.M.G. 1911. Recherches sur les musulmans chinois. [Documents scientifiques de la Mission d'Ollone 1]. Paris.

$E I=$ Algar (1985).

Pulleyblank E.G. 1991. Lexicon of reconstructed pronunciation in Early Middle Chinese, Late Middle Chinese, and Early Mandarin. Vancouver.

Schuessler A. 2007. ABC etymological dictionary of Old Chinese. Honolulu.

2 Personal communication (May 4, 2019).

3 Information provided by Dr. Aysima Mirsultan (personal communication, May 2, 2019).

4 In the town of Liáochéng exist two mosques called by their location in the old town: the older "East mosque", sometimes called "Great mosque" and the later built "West mosque". 